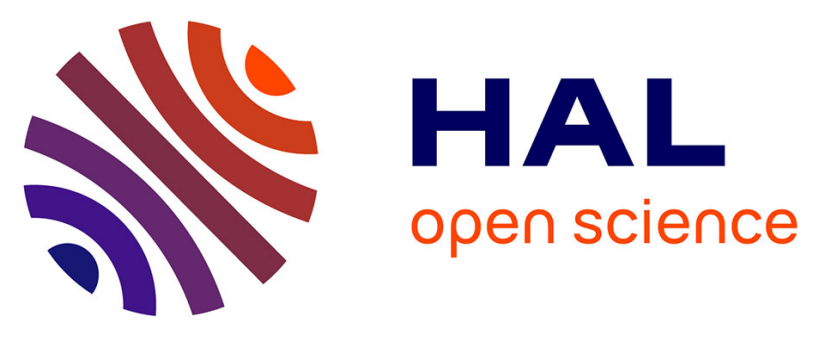

\title{
Pressure-induced retention of second polar body and suppression of first cleavage in rainbow trout: Production of all-triploids, all-tetraploids, and heterozygous and homozygous diploid gynogenetics
}

Daniel Chourrout

\section{To cite this version:}

Daniel Chourrout. Pressure-induced retention of second polar body and suppression of first cleavage in rainbow trout: Production of all-triploids, all-tetraploids, and heterozygous and homozygous diploid gynogenetics. Aquaculture, 1984, 36 (1-2), pp.111-126. 10.1016/0044-8486(84)90058-9 . hal01601159

\author{
HAL Id: hal-01601159 \\ https://hal.science/hal-01601159
}

Submitted on 2 Jun 2020

HAL is a multi-disciplinary open access archive for the deposit and dissemination of scientific research documents, whether they are published or not. The documents may come from teaching and research institutions in France or abroad, or from public or private research centers.
L'archive ouverte pluridisciplinaire HAL, est destinée au dépôt et à la diffusion de documents scientifiques de niveau recherche, publiés ou non, émanant des établissements d'enseignement et de recherche français ou étrangers, des laboratoires publics ou privés.

\section{()(1)(2)}

Distributed under a Creative Commons Attribution - ShareAlikel 4.0 International 


\title{
PRESSURE-INDUCED RETENTION OF SECOND POLAR BODY AND SUPPRESSION OF FIRST CLEAVAGE IN RAINBOW TROUT: PRODUCTION OF ALL-TRIPLOIDS, ALL-TETRAPLOIDS, AND HETEROZYGOUS AND HOMOZYGOUS DIPLOID GYNOGENETICS
}

\section{DANIEL CHOURROUT}

Laboratoire de Physiologie des Poissons, CNRZ-INRA, 78350 Jouy-en-Josas (France) (Accepted 25 February 1983)

\begin{abstract}
Chourrout, D., 1984. Pressure-induced retention of second polar body and suppression of first cleavage in rainbow trout: production of all-triploids, all-tetraploids, and heterozygous and homozygous diploid gynogenetics. Aquaculture, 36: 111-126.
\end{abstract}

Retention of the second polar body in rainbow trout eggs was induced by 7000 psi early pressure shocks (applied $40 \mathrm{~min}$ after insemination) lasting $4 \mathrm{~min}$. This resulted in all-triploid progenies after fertilization with functional sperm, and in high yields of heterozygous diploid gynogenetic fry after insemination with gamma-irradiated sperm.

All-tetraploid progenies were produced by 7000 psi late pressure shocks (applied $5 \mathrm{~h} 50 \mathrm{~min}$ after insemination) lasting $4 \mathrm{~min}$, if normal sperm had been used. With eggs activated by gamma-irradiated sperm, these shocks resulted in diploid gynogenetic embryos that were supposed to be homozygous at all their loci because obviously they result from the fusion of two mitotic products. This fact may explain their very low post-hatching survival, but the occurrence of residual chromosome fragments of paternal origin in their cells, demonstrated by an extensive karyological investigation, could also be responsible of the poor yields; such an observation suggests that we abandon the use of gamma irradiation for sperm inactivation.

Finally, tetraploid hybrid embryos were produced with similar late pressure shocks applied after heterospecific inseminations.

\section{INTRODUCTION}

In the reproduction of most domestic birds and mammals, two diploid parents of the same species give rise to a diploid offspring after meiosis and fertilization; in such conditions the breeder has to determine which parents will be involved in the reproduction of his population.

In commercial fish, deviations from the normal reproduction pattern can be induced easily: parents of two different species (hybridization), only one parent (gynogenesis and androgenesis) or increase of chromosome number (polyploidy). These phenomena can be exploited in planning new schemes of genetic improvement for animal breeding (but already classical 


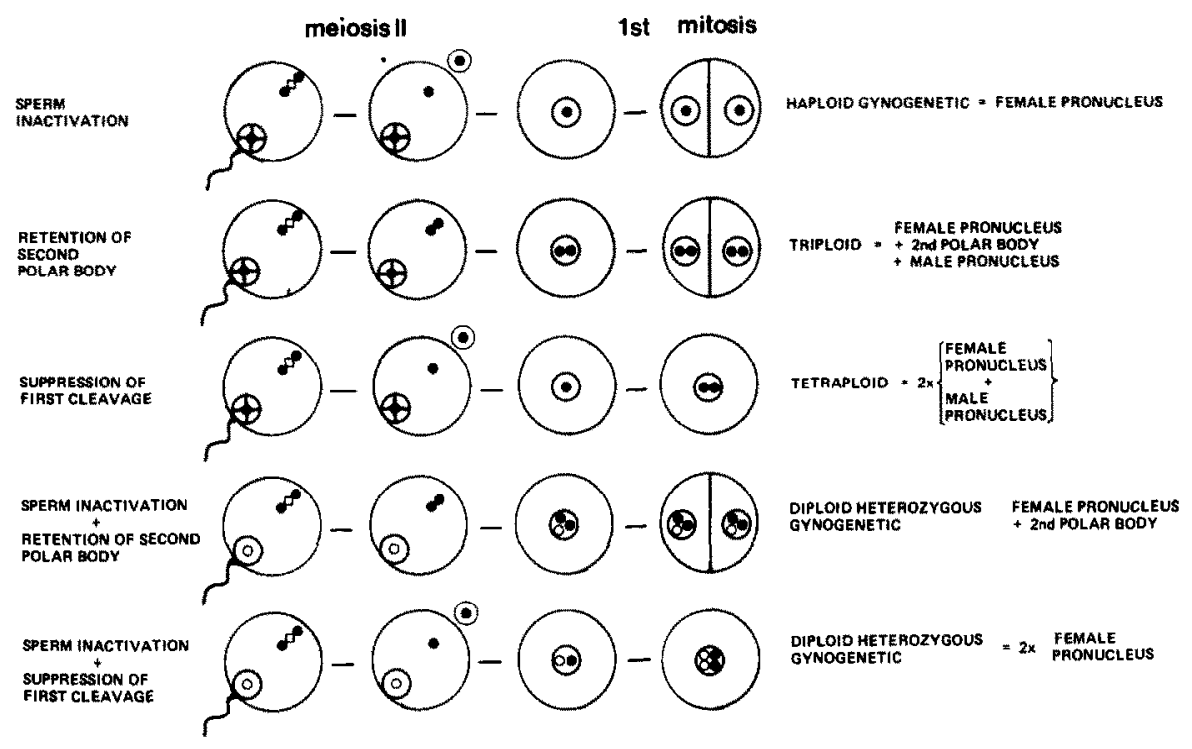

Fig. 1. Three operations are required for producing gynogenetic individuals, triploids and tetraploids in lower vertebrates: sperm inactivation, retention of second polar body and suppression of first cleavage.

in plants), such as the crossing of inbred lines (produced by gynogenesis) or the use of polyploids.

In this respect, diploid gynogenetic individuals and polyploids could be produced if three techniques were available, viz. genetic inactivation of sperm, induced retention of the second polar body, and induced suppression of first cleavage (see Fig. 1). Diploid gynogenesis requires the combination of sperm inactivation and diploidization of the maternal chromosome set. If the later is achieved by retention of the second polar body, the resulting embryo starts from two differing terminal products of the same meiosis and so is not homozygous at all the loci (such embryos are called heterozygous diploid gynogenetics in the text). If suppression of first cleavage is used to diploidize the maternal set, the collected embryos are considered to be homozygous at all the loci because they result from the fusion of two mitotic products.

Such techniques have been applied recently in many fish species (Table I) with the object of producing inbred lines or monosex populations by gynogenesis and sterile animals by polyploidy. These investigations are based on methods first developed with amphibians (review Chourrout, 1982a).

In the case of salmonid fishes, sperm inactivation is usually performed with gamma rays, a choice discussed in this paper. Retention of the second polar body is systematically induced by treating eggs with short heat shocks soon after insemination, resulting in all-triploid progenies if functional sperm are used, and in high yields of heterozygous gynogenetics after in- 


\section{TABLE I}

Authors having induced sperm inactivation, retention of the second polar body and the suppression of first cleavage in fish. Parentheses Indicate studies resulting in low yields

Sperm inactivation

\begin{tabular}{lll}
\hline & Agents used & \\
\cline { 2 - 3 } & Ionizing rays & Ultraviolet rays \\
\hline $\begin{array}{l}\text { Fish other } \\
\text { than } \\
\text { salmonids }\end{array}$ & $\begin{array}{l}\text { Lasher and Rugh, 1962 } \\
\text { Romashov et al., 1963 } \\
\text { Golovinskaï et al., 1963 } \\
\text { Cherfas, 1965 } \\
\text { Purdom, 1969 }\end{array}$ & $\begin{array}{l}\text { Streinley, 1976 } \\
\text { al., 1981 } \\
\text { Chourrout and } \\
\text { Itskovich, 1983 }\end{array}$ \\
Salmonids & $\begin{array}{l}\text { Purdom, 1969 } \\
\text { Chourrout et al., 1980 } \\
\text { Onozato, 1982 }\end{array}$ & Chourrout, 1982c \\
\hline
\end{tabular}

Retention of second polar body

\begin{tabular}{|c|c|c|c|c|}
\hline & \multicolumn{4}{|l|}{ Agents used } \\
\hline & Cold shocks & Heat shocks & $\begin{array}{l}\text { Pressure } \\
\text { shocks }\end{array}$ & Colchicine \\
\hline $\begin{array}{l}\text { Fish other } \\
\text { than } \\
\text { salmonids }\end{array}$ & $\begin{array}{l}\text { Swarup, } 1958 \\
\text { (Cherfas, 1965) } \\
\text { Purdom, 1969 } \\
\text { Nagy et al., 1978 } \\
\text { Ojima and Makino, } 1978 \\
\text { Wolters et al., } 1981\end{array}$ & $\begin{array}{l}\text { Swarup, } 1958 \\
\text { Romashov and } \\
\text { Belyaeva, } 1965 \\
\text { Valenti, } 1975 \\
\text { Chourrout and } \\
\text { Itskovich, } 1983\end{array}$ & $\begin{array}{l}\text { Streisinger et } \\
\text { al., } 1981\end{array}$ & \\
\hline Salmonids & $\begin{array}{l}\text { Chourrout, } 1980 \\
\text { Lemoine and Smith, } \\
1980 \\
\text { Refstie et al., } 1982\end{array}$ & $\begin{array}{l}\text { Chourrout, } 1980 \\
\text { Thorgaard et } \\
\text { al., } 1981\end{array}$ & & $\begin{array}{l}\text { Smith and } \\
\text { Lemoine } \\
1979\end{array}$ \\
\hline \multicolumn{5}{|c|}{ Suppression of first cleavage } \\
\hline & \multicolumn{4}{|l|}{ Agents used } \\
\hline & Cytochalasin B & Heat shocks & $\begin{array}{l}\text { Pressure } \\
\text { shocks }\end{array}$ & \\
\hline $\begin{array}{l}\text { Fish other } \\
\text { than } \\
\text { salmonids }\end{array}$ & & & $\begin{array}{l}\text { Streisinger et } \\
\text { al., } 1981\end{array}$ & \\
\hline Salmonids & $\begin{array}{l}\text { Refstie et al., } 1977 \\
\text { Allen and Stanley, } 1979 \\
\text { Refstie, } 1981\end{array}$ & $\begin{array}{l}\text { (Thorgaard et } \\
\text { al., 1981) } \\
\text { (Chourrout, 1982b) }\end{array}$ & & \\
\hline
\end{tabular}


semination with irradiated sperm. However, chromosome doubling by suppression of first cleavage has not yet been satisfactorily achieved in spite of several attempts with heat shocks and cytochalasin B. This paper summarizes our successful attempts at inducing suppression of first cleavage by means of hydrostatic pressure shocks, which have been shown to be effective for doubling haploid eggs in the fish Brachydanio rerio (Streisinger et al., 1981) and of both haploid and diploid eggs in the leopard frog Rana pipiens (Reindschmidt et al., 1979). Because of the difficulty in optimizing three parameters (pressure level, shock duration and time of application, the latter being difficult to estimate a priori), we calibrated the two parameters of shock intensity in attempts to retain the second polar body. In fact, we could test a limited number of times of application in this case, according to previous results obtained with heat shocks (Chourrout, 1980).

\section{MATERIALS AND METHODS}

\section{Fertilization}

In order to get enough eggs for large experiments, we used in most cases mixtures of ova collected from several females (at least four). In one case, yields of gynogenetic individuals provided by six females were compared, fertilization was carried out by mixing 500 eggs with 0.05 to $0.50 \mathrm{ml}$ of pure milt and $25 \mathrm{ml}$ of a saline-buffered diluent (Billard, 1974); $10 \mathrm{~min}$ later, the eggs were transferred into a thermoregulated $\left(9.4^{\circ} \mathrm{C}\right)$ recirculating system for incubation (zero development time).

\section{Sperm irradiation}

In order to induce gynogenesis, pure sperm was collected in tubes and submitted to Cobalt-60 irradiation (135 krad except in one case where effects of 100 and $135 \mathrm{krad}$ were compared, see Results, section 3).

\section{Pressure treatments}

In order to induce retention of the second polar body and suppression of first cleavage, we tested early pressure shocks (EP shocks) applied in the first hour of development, and late pressure shocks (LP shocks) applied between 4 and $8 \mathrm{~h}$ after insemination. Each treatment consisted in placing 250 to 500 eggs in a stainless steel cylinder full of water at 9.4 ${ }^{\circ} \mathrm{C}$ and closed by a piston; the pressure level was raised with an external hydraulic press and reached 6000 or 7000 psi after $3 \mathrm{~s}$; decompression was instantaneous at the end of the treatment which lasted 2 to $12 \mathrm{~min}$; the machine used here belongs to the Laboratory of Animal Biology of Toulouse University and had already been used in the induction of second 
polar body retention in the newt Pleurodeles waltlii (Jaylet and Ferrier, 1978; Ferrier and Jaylet, 1978).

\section{Survival rates}

Counts of survivors were made in the different batches at tail bud stage (eyed stage; day 18 to day 26), after hatching (day 35 to day 40 ) and, in many cases, at the start of feeding (day 55 to day 60 ).

In the experiments on gynogenesis, the hatching rate was the first criterion for estimating the success of induced diploidization, since all the haploid embryos die before this stage. It must, in any case, be confirmed by karyological examinations.

\section{Karyology}

In attempts at polyploidization and at sperm inactivation, the effectiveness of treatments was ascertained by chromosome counts on embryos or on hatched fry.

Embryos. On day 17, the eggs were placed for $6 \mathrm{~h}$ in a $0.02 \%$ colchicine solution, and then dissected in $0.7 \% \mathrm{NaCl}$ for removal of the embryo. The tail was cut and subjected to a hypotonic treatment (15 min in distilled water), fixed in ethanol $3 /$ acetic acid 1 for $3 \mathrm{~min}$ and rinsed in distilled water; the tail epithelium was gently dissociated in a drop of $50 \%$ acetic acid.

Hatched fry. On day 45 , the fry were kept swimming for $15 \mathrm{~h}$ in a $0.01 \%$ colchicine solution. After killing, the gills were removed, put in distilled water for $45 \mathrm{~min}$, fixed for $3 \mathrm{~min}$ and finally dissociated.

In both cases, the cellular suspension was dropped onto a warmed (50 $\left.{ }^{\circ} \mathrm{C}\right)$ microscopic slide, air-dried, and stained in $4 \%$ Giemsa for $10 \mathrm{~min}$. Each investigation concerned at least 15 individuals in a batch.

\section{RESULTS}

\section{(1) Retention of second polar body induced by early pressure shocks}

\section{A. Fertilization with irradiated sperm}

Initial experiments showed that 6000 psi EP shocks lasting 8 min resulted in high hatching rates, whereas all the embryos died in the control (irradiated sperm; no pressure shock). Fig. 2a shows a maximum survival with shocks applied at 20 and 40 min after insemination for hatched fry and at $40 \mathrm{~min}$ for fry at the start of feeding.

At $7000 \mathrm{psi}$, EP shocks applied $40 \mathrm{~min}$ after insemination gave the best results when shock duration was $3.5-5$ min (Fig. $2 b$ ).

Karyological investigations of progenies revealed only diploid complements, whereas all the analysed embryos of the control proved to be haploid. 

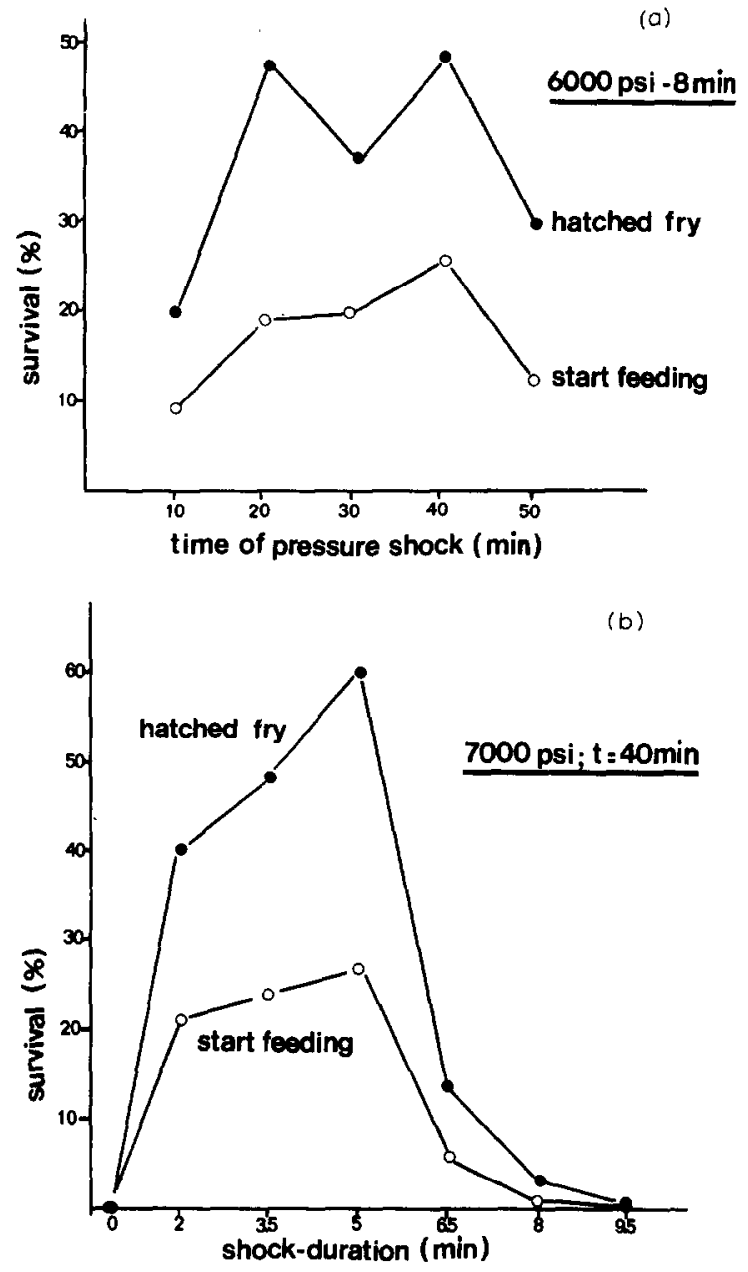

Fig. 2. Percentages of viable gynogenetic individuals obtained from eggs treated with various EP shocks (applied after fertilization with irradiated sperm: (a) optimization of preshock duration with 6000 psi shocks; (b) optimization of shock duration at 7000 psi for shocks applied $40 \mathrm{~min}$ after insemination.

Table II shows that yields of viable gynogenetic individuals at hatching time and at the feeding stage varied appreciably according to the female used.

\section{B. Fertilization with functional sperm}

Treatments with 6000 psi applied $10 \mathrm{~min}$ after fertilization with untreated sperm, and lasting 2 to $12 \mathrm{~min}$, provided the following results:

(a) The embryonic survival rate was not appreciably decreased by shocks lasting up to $8 \mathrm{~min}$. Nevertheless, most of the embryos from the 4-min treatment were abnormal and died without hatching, whereas most of 


\section{TABLE II}

Percentages of treated eggs giving viable hatched fry $(\mathrm{H})$ and feeding fry $(\mathrm{F})$ for six females subjected to gynogenesis with retention of the second polar body (7000 psi shocks lasting $4 \mathrm{~min}$ applied $40 \mathrm{~min}$ after insemination with irradiated sperm)

\begin{tabular}{|c|c|c|c|c|c|c|c|}
\hline & & \multicolumn{6}{|c|}{ Females } \\
\hline & & 1 & 2 & 3 & 4 & 5 & 6 \\
\hline $\begin{array}{l}\text { Diploid } \\
\text { control }\end{array}$ & $\begin{array}{l}\mathrm{H}: \\
\mathrm{F}:\end{array}$ & $\begin{array}{r}100 \\
96\end{array}$ & $\begin{array}{l}98 \\
88\end{array}$ & $\begin{array}{l}92 \\
92\end{array}$ & $\begin{array}{l}86 \\
76\end{array}$ & $\begin{array}{l}99 \\
95\end{array}$ & $\begin{array}{l}58 \\
55\end{array}$ \\
\hline $\begin{array}{l}\text { Gynogenetic } \\
\text { individuals }\end{array}$ & $\begin{array}{l}\text { H: } \\
\text { F: }\end{array}$ & $\begin{array}{l}43 \\
37\end{array}$ & $\begin{array}{l}82 \\
61\end{array}$ & $\begin{array}{l}79 \\
78\end{array}$ & $\begin{array}{l}36 \\
24\end{array}$ & $\begin{array}{l}73 \\
73\end{array}$ & $\begin{array}{l}18 \\
17\end{array}$ \\
\hline
\end{tabular}

\section{TABLE III}

Karyological results provided by the examination of embryos after 6000 psi shocks lasting 2 to $8 \mathrm{~min}$ applied $10 \mathrm{~min}$ after fertilization with normal sperm

\begin{tabular}{|c|c|c|c|c|c|c|}
\hline Shock duration (mi) & & 0 & 2 & 4 & 68 & \\
\hline Abnormal embryos & $\begin{array}{l}\text { analysed } \\
\text { diploids } \\
\text { triploids } \\
\text { aneuploids }\end{array}$ & $\begin{array}{l}0 \\
- \\
-\end{array}$ & $\begin{array}{l}8 \\
3 \\
1 \\
4\end{array}$ & $\begin{array}{l}8 \\
2 \\
0 \\
6\end{array}$ & $\begin{array}{ll}8 & 0 \\
2 & - \\
0 & - \\
6 & -\end{array}$ & - \\
\hline Normal embryos & $\begin{array}{l}\text { analysed } \\
\text { diploids } \\
\text { triploids } \\
\text { aneuploids }\end{array}$ & $\begin{array}{r}10 \\
10 \\
0 \\
0\end{array}$ & $\begin{array}{l}8 \\
8 \\
0 \\
0\end{array}$ & $\begin{array}{l}6 \\
1 \\
5 \\
0\end{array}$ & $\begin{array}{rr}8 & 15 \\
3 & 0 \\
5 & 15 \\
0 & 0\end{array}$ & $\begin{array}{l}5 \\
0 \\
5 \\
0\end{array}$ \\
\hline
\end{tabular}
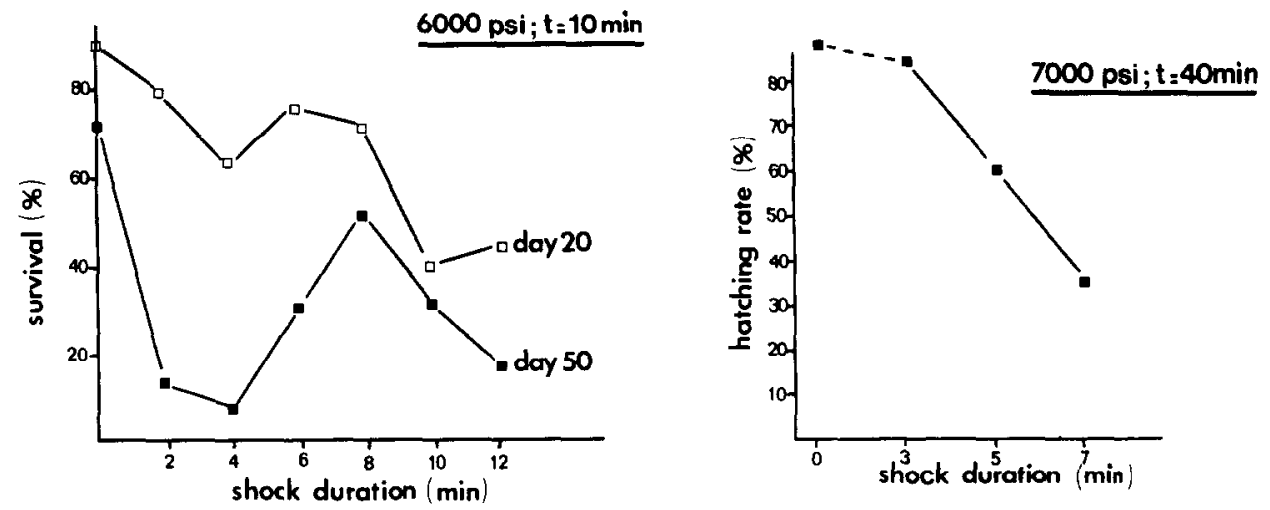

Fig. 3. Survival at tail bud stage (day 20) and after hatching (day 50) following 6000 EP shocks applied 10 min after fertilization with normal sperm (percentage of treated eggs).

Fig. 4. Hatching rates following 7000 psi shocks applied 40 min after fertilization with normal sperm. All the fry analysed were triploid. 

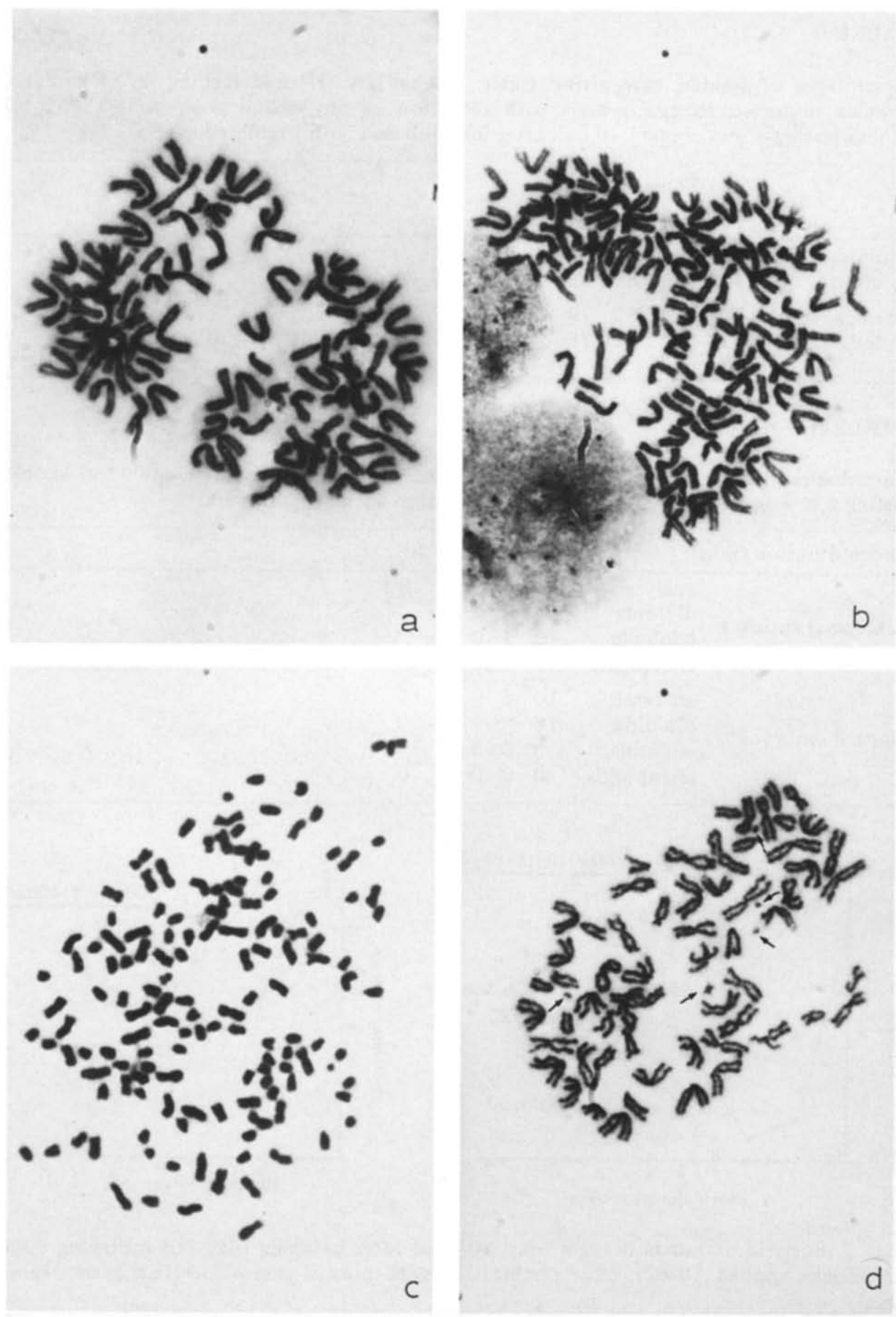

Fig. 5. Metaphases obtained on embryos produced by EP shocks (a: triploid) and by LP shocks (b: tetraploid; c: allotetraploid "female rainbow trout $x$ male brown trout"; d: homozygous diploid gynogenetic individuals with residues of paternal chromatin arrows). 
the embryos from the 8-min shock were normal and survived after hatching (Fig. 3).

(b) These observations were supported by the karyological data (Table III): in the 4- and 6-min batches, most of the abnormal embryos analysed were aneuploids (hyperdiploids and hypotriploids), and most of the normal ones were triploid; in the 8-min batch, all the embryos analysed were triploid (Fig. 5a).

Treatments with 7000 psi EP shocks (the optimum found in the experiments on gynogenesis) resulted here in all-triploid offspring, with satisfactory hatching rates (Fig. 4).

\section{(2) Suppression of first cleavage induced by late pressure shocks}

\section{A. Fertilization with functional rainbow trout sperm}

Treatments with various LP shocks provided the following results, illustrated by Figs. 6 and 7 :

(a) Treatments applied earlier than $5 \mathrm{~h}$ and later than $7 \mathrm{~h}$ after fertilization systematically resulted in rapid abortions.

(b) High survival rates were counted at tail bud stage for shocks applied $5 \mathrm{~h} 20 \mathrm{~min}$ and $5 \mathrm{~h} 50 \mathrm{~min}$ after insemination and lasting 4 and $5.5 \mathrm{~min}$. This procedure, when repeated, gave lower but satisfactory survival rates at the same stage, but the same peak of survival between 5 and $7 \mathrm{~h}$ was always registered.

(c) All the embryos analysed were tetraploid (Fig. 5b).

(d) Fig. 7 shows that significant mortalities occurred until the feeding stage; they consisted mostly in an elimination of abnormal fry, the survivors at this time being almost all normal in appearance and proving to be all-tetraploid by a new karyological investigation.

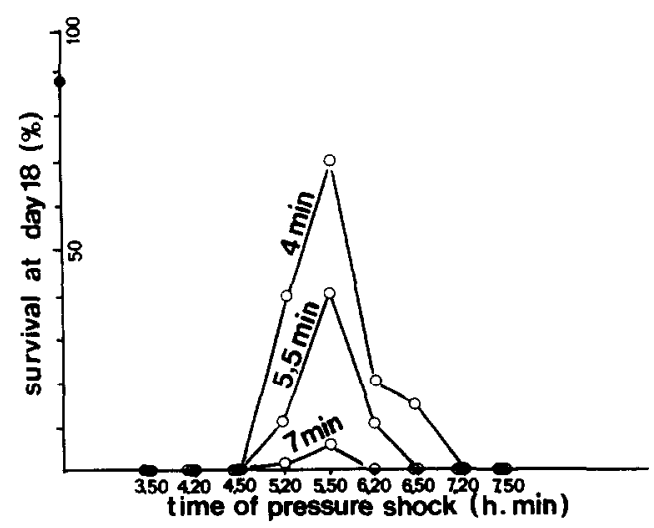

Fig. 6. Survival at tail bud stage (percentage of treated eggs) after 7000 psi LP shocks lasting 4,5.5 and $7 \mathrm{~min}$, and applied between $3 \mathrm{~h} 50 \mathrm{~min}$ and $7 \mathrm{~h} 20 \mathrm{~min}$ after fertilization with normal sperm. 


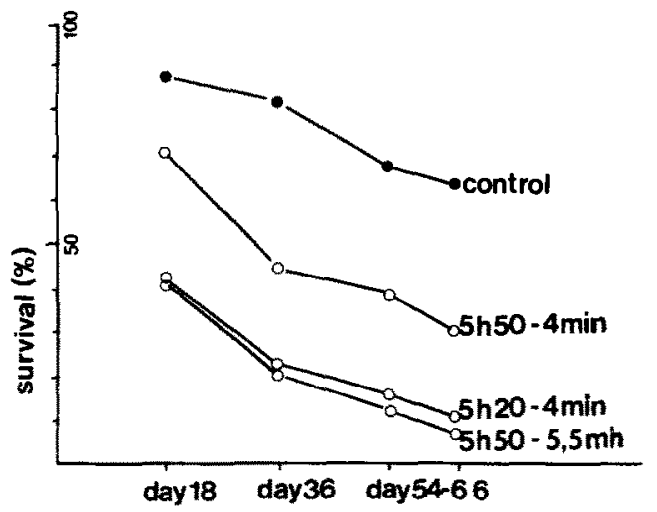

Fig. 7. Survival until the start of feeding (percentage of treated eggs) of four batches subjected to LP shocks after insemination with normal sperm.

\section{B. Fertilization with functional heterologous sperm}

The optimal LP shock, applied $5 \mathrm{~h} 50$ min after fertilization with brown trout and coho salmon sperm, respectively, provided $12 \%$ and $19 \%$ survivors at the tail bud stage. This preliminary experiment was stopped before hatching but all the embryos analysed proved to be allotetraploid (Fig. 5c).

C. Fertilization with irradiated rainbow trout sperm

Various LP shocks were tested after insemination with inactivated sperm and some of them, lasting $3 \mathrm{~min}$, appreciably increased the hatching rate,

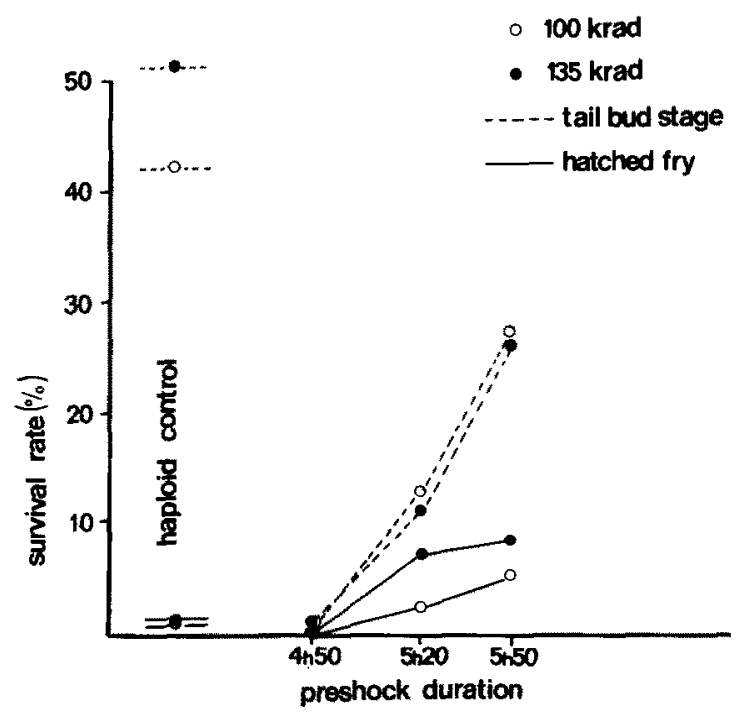

fig. 8. Survival at the tail bud stage and after hatching (percentage of treated eggs) after 7000 psi LP shocks lasting $3 \mathrm{~min}$ and applied $4 \mathrm{~h} 50 \mathrm{~min}, 5 \mathrm{~h} 20 \mathrm{~min}$ and $5 \mathrm{~h} 50$ min after insemination with irradiated sperm. 
if compared with the haploid control (Fig. 8). At the tail bud stage, karyological examinations revealed only diploid embryos (Fig. 5d) versus only haploid ones in the control. However, the yield of these supposed homozygous diploid individuals was considered very low (32 fry collected from 389 treated eggs in the best case: $7000 \mathrm{psi}$ lasting $3 \mathrm{~min}$ and applied $5 \mathrm{~h}$ 50 min after insemination).

(3) Karyological investigations of various types of gynogenetic individuals and their corresponding survival rates

Supernumerary chromosome fragments were detected in the cells of all the gynogenetic embryos analysed; their number varied considerably according to the observed metaphase in a given embryo. For a given batch, the distribution of their frequency per metaphase was determined from observation of 15 embryos and grouping of these results. This investigation was performed for six batches of gynogenetic individuals: three types (haploid, heterozygous diploid obtained after retention of the second polar body, homozygous diploid obtained after suppression of first cleavage) and two doses of sperm irradiation for each type (100 and $135 \mathrm{krad}$ ). The results are presented in Fig. 9:

(a) For a given type of embryo, the mean number of fragments per

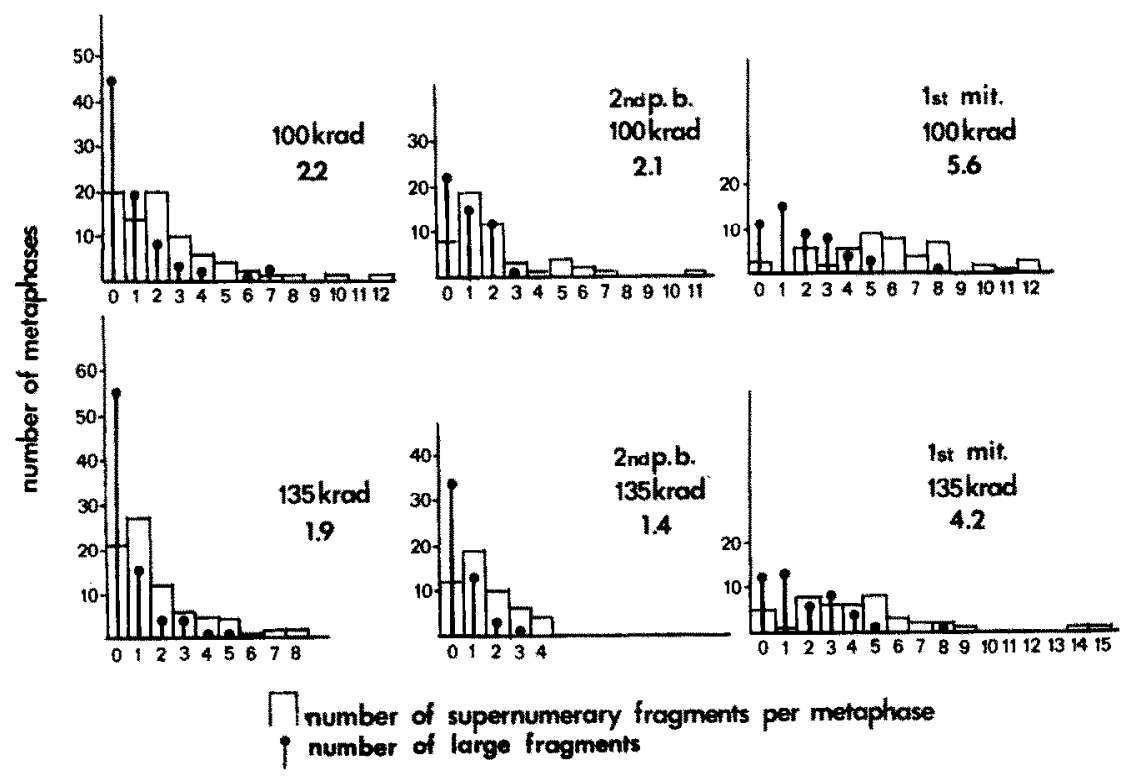

Fig. 9. Large numbers of supernumerary fragments were detected in the metaphases of gynogenetic embryos by karyological examination. Their distribution is presented here for six batches (two doses of sperm irradiation $x$ three types of gynogenetics: haploids, heterozygous diploids and homozygous diploids). For each graph, the mean number of fragments per cell is given. 
TABLE IV

Survival at tail bud stage, hatching time and start of feeding of gynogenetic individuals produced by EP and LP shocks

\begin{tabular}{|c|c|c|c|c|c|c|c|}
\hline $\begin{array}{l}\text { Time after } \\
\text { fertilization } \\
\text { of shock }\end{array}$ & $\begin{array}{l}\text { Shock } \\
\text { duration } \\
\text { (min) }\end{array}$ & $\begin{array}{l}\text { Sperm irra- } \\
\text { diation dose } \\
\text { (krad) }\end{array}$ & $\begin{array}{l}\text { Treated } \\
\text { eggs } \\
\text { (no) }\end{array}$ & $\begin{array}{l}\text { Tail bud } \\
\text { stage }\end{array}$ & $\begin{array}{l}\text { Hatching } \\
\text { stage }\end{array}$ & $\begin{array}{l}\text { Feeding } \\
\text { stage }\end{array}$ & $\begin{array}{l}\text { Tail bud stage } \\
\text { to } \\
\text { teeding stage }\end{array}$ \\
\hline $40 \mathrm{~min}$ & 3 & $\begin{array}{l}100 \\
135\end{array}$ & $\begin{array}{l}235 \\
271\end{array}$ & $\begin{array}{l}70 \\
61\end{array}$ & $\begin{array}{l}66 \\
59\end{array}$ & $\begin{array}{l}54 \\
56\end{array}$ & $\begin{array}{l}84 \\
91\end{array}$ \\
\hline $40 \mathrm{~min}$ & 4 & $\begin{array}{l}100 \\
135\end{array}$ & $\begin{array}{l}261 \\
270\end{array}$ & $\begin{array}{l}67 \\
60\end{array}$ & $\begin{array}{l}59 \\
54\end{array}$ & $\begin{array}{l}52 \\
47\end{array}$ & $\begin{array}{l}77 \\
78\end{array}$ \\
\hline $40 \mathrm{~min}$ & 5 & $\begin{array}{l}100 \\
135\end{array}$ & $\begin{array}{l}300 \\
248\end{array}$ & $\begin{array}{l}63 \\
68\end{array}$ & $\begin{array}{l}58 \\
50\end{array}$ & $\begin{array}{l}48 \\
45\end{array}$ & $\begin{array}{l}77 \\
67\end{array}$ \\
\hline Total EP shc & cks & $\begin{array}{l}100 \\
135\end{array}$ & $\begin{array}{l}796 \\
789\end{array}$ & $\begin{array}{l}66 \\
63\end{array}$ & $\begin{array}{l}61 \\
54\end{array}$ & $\begin{array}{l}51 \\
49\end{array}$ & $\begin{array}{l}77 \\
79\end{array}$ \\
\hline $5 \mathrm{~h} 20 \mathrm{~min}$ & 3 & $\begin{array}{l}100 \\
135\end{array}$ & $\begin{array}{l}386 \\
403\end{array}$ & $\begin{array}{l}13 \\
11\end{array}$ & $\begin{array}{l}2 \\
7\end{array}$ & $\begin{array}{l}0 \\
4\end{array}$ & $\begin{array}{r}2 \\
42\end{array}$ \\
\hline $5 \mathrm{~h} 20 \mathrm{~min}$ & 4 & $\begin{array}{l}100 \\
135\end{array}$ & $\begin{array}{l}447 \\
436\end{array}$ & $\begin{array}{l}8 \\
6\end{array}$ & $\begin{array}{l}2 \\
2\end{array}$ & $\begin{array}{l}0.5 \\
1\end{array}$ & $\begin{array}{r}6 \\
15\end{array}$ \\
\hline $5 \mathrm{~h} 60 \mathrm{~min}$ & 3 & $\begin{array}{l}100 \\
135\end{array}$ & $\begin{array}{l}367 \\
\mathbf{3 8 9}\end{array}$ & $\begin{array}{l}27 \\
26\end{array}$ & $\begin{array}{l}5 \\
8\end{array}$ & $\begin{array}{l}\mathbf{1} \\
\mathbf{3}\end{array}$ & $\begin{array}{r}2 \\
10\end{array}$ \\
\hline $5 \mathrm{~h} 50 \mathrm{~min}$ & 4 & $\begin{array}{l}100 \\
135\end{array}$ & $\begin{array}{l}374 \\
397\end{array}$ & $\begin{array}{l}16 \\
14\end{array}$ & $\begin{array}{l}4 \\
5\end{array}$ & $\begin{array}{l}\mathbf{1} \\
\mathbf{3}\end{array}$ & $\begin{array}{r}5 \\
19\end{array}$ \\
\hline \multicolumn{2}{|c|}{ Total LP shocks } & $\begin{array}{l}100 \\
135\end{array}$ & $\begin{array}{l}1574 \\
1615\end{array}$ & $\begin{array}{l}16 \\
20\end{array}$ & $\begin{array}{l}4 \\
5\end{array}$ & $\begin{array}{l}1 \\
3\end{array}$ & $\begin{array}{r}5 \\
19\end{array}$ \\
\hline \multicolumn{2}{|c|}{ Control, no shock } & $\begin{array}{l}100 \\
135\end{array}$ & $\begin{array}{l}313 \\
334\end{array}$ & $\begin{array}{l}42 \\
51\end{array}$ & $\begin{array}{l}1 \\
1\end{array}$ & $\begin{array}{l}0 \\
0\end{array}$ & $\begin{array}{l}0 \\
0\end{array}$ \\
\hline
\end{tabular}

cell was not appreciably decreased by the use of $135 \mathrm{krad}$ instead of 100 krad: 1.9 versus 2.2 for haploids, 1.4 versus 2.1 for heterozygous diploids, and 4.2 versus 5.6 for homozygous diploids.

(b) However, we could ascertain, with the help of a rather arbitrary distinction between small fragments (point size) and larger ones (but always smaller than trout chromosomes), that the mean size of the supernumerary fragments was reduced by the use of $135 \mathrm{krad}$.

(c) For a given irradiation dose, it is evident that cells of homozygous embryos contained on average many more fragments (about twice as many) than did cells of heterozygous and haploid embryos.

These results have to be related to the survival rates recorded in the batches of the same experiment. In fact, many batches were studied, corresponding to one control, three EP shocks, and four LP shocks, with a comparison of the effects of 100 and $135 \mathrm{krad}$ in each case; the results from tail bud stage to the start of feeding are presented in Table IV:

(a) The yields of heterozygous gynogenetics are much higher than the yields of homozygous ones (particularly if the numbers of tail bud embryos providing feeding fry are compared).

(b) It is important to note that the yields of homozygous individuals were improved by the use of $135 \mathrm{krad}$, whereas yields after EP shocks did not differ according to the irradiation dose. 


\section{DISCUSSION AND CONCLUSION}

\section{Technical aspects}

The results demonstrate that hydrostatic pressure is very effective in inducing the retention of the second polar body. The yields of heterozygous gynogenetic individuals at the start of feeding can be compared with those following heat shocks, and all-triploid offspring are easily obtained with the same optimized EP treatments. Treatments of lower intensities induce incomplete retention of the second polar body, leading to inviable aneuploids. In this respect, a high frequency of abnormal embryos resulting from a pressure treatment can indicate that the tested shock is not strong enough: in such a case, an increase of intensity should improve the rate of normal individuals.

Most of the rainbow trout eggs treated with LP shocks at $5 \mathrm{~h} 50 \mathrm{~min}$ after fertilization with normal sperm gave viable embryos which were all tetraploid. The low rates of tetraploidy previously obtained with late heat shocks (Chourrout, 1982b) had been interpreted by supposing that the eggs are sensitive to such heat shocks only during a very short period of their development. The induction of tetraploidy by heat shocks in amphibians requires a preliminary selection of sensitive eggs, based on observation of the cleavage furrow with the naked eye: this is impossible in salmonids because the egg shell is not transparent at this stage. Pressure treatments are far more effective in our case, and probably act on less critical stages of first mitosis, but it could be possible to obtain good results with heat shocks in species having transparent eggs. Late pressure shocks are also effective for the production of allotetraploid embryos, without requiring any additional optimization, at least in the case of the two hybridizations tested here which use the rainbow trout as the maternal species.

With similar LP shocks following an insemination with gamma-irradiated sperm, we have obtained high frequencies of diploid gynogenetic embryos. They were supposed to be completely homozygous, a condition that could explain their high mortality before hatching and during yolk resorption. However, the karyological investigations performed here demonstrate the occurrence of supernumerary chromosome fragments in the cells of these homozygous embryos, probably due to their replication before the inhibition of first cleavage. The fact that the use of 135 instead of $100 \mathrm{krad}$ for sperm inactivation, that decreases the mean size of these fragments, was associated with an improvement in survival suggests a depressive effect caused by a contamination of the maternal genome by residual chromatin. Therefore, the poor survival of homozygous individuals could in part be attributed to the use of gamma rays for sperm inactivation. Our primary objective was to determine a way of suppressing first cleavage, but the work also demonstrates the inefficiency of gamma rays for 
inducing a "clean" sperm inactivation and suggests abandoning the use of this agent, although a recent study on chum salmon does not mention any supernumerary fragments in embryos following a 100-krad sperm irradiation (Onozato, 1982).

Similar karyological investigations have to be repeated in the case of ultraviolet irradiation, but the results obtained up to now in trout are very encouraging because no fragments have been detected with the optimal UV treatments (Chourrout, 1982c). In addition, the induction of gynogenesis in tilapia, recently performed with ultraviolet irradiation of sperm (Chourrout and Itskovich, 1983), has not resulted in the detection of any residual fragments.

\section{Future prospects of chromosome doubling in fish}

Tetraploidy. Tetraploidy is not considered to be an effective method for improving growth in animals. This idea is based in part on the observation of very low numbers of tetraploid amphibians produced directly from diploid eggs, but strictly these should be considered as double-diploids. Careful comparison with appropriate diploid controls is required, and several generations of mating between tetraploids (a necessary procedure for optimizing the level of heterozygosity) should be achieved before drawing any conclusion about this important question.

If tetraploids actually produce high rates of diploid gametes, they could be used in matings to produce triploid sterile animals. The resulting heterozygosity would be higher than by direct retention of the second polar body. In addition, the possibility of tetraploid females producing larger ovocytes could justify this method.

Homozygous diploidy. Homozygous diploid gynogenetic individuals can be mated in order to produce clones for various experiments (Streisinger et al., 1981), even if they are produced in low numbers.

Our opinion is that production of inbred strains for genetic improvement of commercial performances will be difficult if started with gynogenesis by suppression of the first cleavage. The low survival rates resulting from this operation probably do not permit the maintenance of lines until reproduction and an eventual selection at this stage.

We would prefer to start such a program by subjecting several females to gynogenesis by retention of the second polar body, although this method is not effective for fixing genes distant from the centromere and although a process of selection for the most "heterozygous" genotypes may occur. The fixation of the lines could be performed in the next generation of gynogenesis, by using the suppression of first cleavage. In this case, better yields could be recorded if in the first generation of inbreeding, natural selection in the lines had eliminated part of the lethal genetic factors. 


\section{REFERENCES}

Allen, S.K. and Stanley, J.G., 1979. Polyploid mosaics induced by cytochalasin B in landlocked Atlantic salmon. Trans. Am. Fish. Soc., 108: 462-466.

Billard, R., 1974. L'insemination artificielle chez la truite Salmo gairdneri Richardson. IV. Effet des ions $\mathrm{K}$ et $\mathrm{Na}$ sur la conservation de la fertilité des gamètes. Bull. Fr. Piscic., 256: 88-100.

Cherfas, N.B., 1965. Investigation of radiation-induced diploid gynogenesis in the carp (Cyprinus carpio L.). I. Experiments on obtaining the diploid gynogenetic progeny in mass quantities. Genetika, 11: 78-86 in Russian.

Chourrout, D., 1980. Thermal induction of diploid gynogenesis and triploidy in the eggs of the rainbow trout (Salmo gairdneri Richardson). Reprod., Nutr., Dévelop., 20: $727-733$.

Chourrout, D., 1982a. La gynogenèse chez les vertébrés. Reprod., Nutr., Dévelop., 22: $713-734$.

Chourrout, D., 1982b. Induction of tetraploidy in the rainbow trout (Salmo gairdneri Richardson) by heat shocks. Reprod., Nutr., Dévelop., 22: 569-574.

Chourrout, D., 1982c. Gynogenesis caused by ultraviolet irradiation of salmonid sperm. J. Exp. Zool., 223: 175-181.

Chourrout, D. and Itskovich, J., 1983. Three manipulations permitted by artificial insemination in Tilapia: Induced diploid gynogenesis, production of all-triploid population and intergeneric hybridization. Proc. Tiberias Symposium on Tilapia in Aquaculture (in press).

Chourrout, D., Chevassus, B. and Hérioux, F., 1980. Analysis of a Hertwig effect in the rainbow trout (Salmo gairdneri Richardson) after fertilization with gamma irradiated sperm. Reprod., Nutr., Dévelop, 20: 719-726.

Ferrier, V. and Jaylet A., 1978. Induction of triploidy in the newt Pleurodeles waltlii by heat shock and hydrostatic pressure. Interpretation of the different types of ploidy using a chromosomal marker. Chromosoma, 69: 47-63.

Golovinskaïa, K.A., Romashov, D.D. and Cherfas, N.B., 1963. Radiation induced gynogenesis in the common carp. Tr. VNIIPRKh., 12: 149-167 (in Russian).

Jaylet, A. and Ferrier, V., 1978. Experimental gynogenesis in the newt species Pleurodeles waltlii and $P$. poireti. Chromosoma, 69: 65-80.

Lasher, R. and Rugh, R., 1962. The "Hertwig effect" in teleost development. Biol. Bull, 123: 582-588.

Lemoine, H.L. and Smith, L.T., 1980. Polyploidy induced in brook trout by cold shock. Trans. Am. Fish. Soc., 109: 626-631.

Nagy, A., Rajki, K., Horvath, L. and Csanyi, V., 1978. Investigation in carp (Cyprinus carpio L.) gynogenesis. J. Fish. Biol., 13: 215-224.

Ojima, Y. and Makino, S., 1978. Triploidy induced by cold shock in fertilized eggs of the carp. Proc. Jpn. Acad., 54: 359-362.

Onozato, H., 1982. The "Hertwig effect" and gynogenesis in chum salmon Oncorhynchus keta eggs fertilized with Co-60 gamma irradiated milt. Bull. Jpn. Soc. Sci. Fish., 48: 1237-1244.

Purdom, C.E., 1969. Radiation induced gynogenesis and androgenesis in fish. Heredity, 24: 431-444.

Refstie, T., 1981. Tetraploid rainbow trout produced by cytochalasin B. Aquaculture, 25: $51-58$.

Refstie, T., Vassvik, V. and Gjedrem, T., 1977. Induction of polyploidy in salmonids by cytochalasin B. Aquaculture, 10: 65-74.

Refstie, T., Stoss, J. and Donaldson, E.M., 1982. Production of all-female coho salmon (Oncorhynchus kisutch) by diploid gynogenesis using irradiated sperm and cold shock. Aquaculture, 29: 67-82. 
Reindschmidt, D.C., Simon, S.J., Volpe, E.P. and Tompkins, R., 1979. Production of tetraploid and homozygous diploid amphibians by suppression of first cleavage. J. Exp. Zool., 210: 137-143.

Romashov, D.D. and Belyaeva, V.N., 1965. Increased yield of diploid gynogenetic loach (Misgurnus fossilis L.) induced by temperature shock. Byull. Mosk. Ova Ispyt. Prir., Otd. Biol., 70: 93-109 (in Russian).

Romashov, D.D., Nikolyukin, N.I., Belyaeva, V.N. and Timofeeva, N.A., 1963. Possibilities of producing diploid radiation induced gynogenesis in sturgeons. Radiobiologiya, 3: 104-109. Translated from Russian in Radiobiology, 3: 145-154.

Smith, L. and Lemoine, H.L, 1979. Colchicine-induced polyploidy in brook trout. Prog. Fish Cult., 41: 86-88.

Stanley, J.G., 1976. Production of hybrid, androgenetic and gynogenetic grass carp and carp. Trans. Am. Fish. Soc., 105: 10-16.

Streisinger, G., Walker, C., Dower, N., Knauber, D. and Singer, F., 1981. Production of clones of homozygous diploid zebrafish (Brachydanio rerio). Nature, 291: 293 $-296$.

Swarup, H., 1958. Production of triploidy in Gasterosteus aculeatus. J. Genetics, 56: $129-142$.

Thorgaard, G.H., Jazwin, M.E. and Stier, A.R., 1981. Polyploidy induced by heat shock in rainbow trout. Trans. Am. Fish. Soc., 110: 546-550.

Valenti, R.F., 1975. Induced polyploidy in Tilapia aurea (Steindachner) by means of temperature shock treatment. J. Fish Biol., 7: 519-528.

Wolters, W.R. Libey, G.S. and Chrisman, C.L., 1981. Induction of triploidy in the channel catfish. Trans. Am. Fish. Soc., 110: 312-314. 